\title{
Organizational culture and job satisfaction: a study Of organized retail sector
}

\author{
Sayeeduzzafar Qazi \\ College of Business Administration \\ University of Business \& Technology, Jeddah, Saudi Arabia \\ Mohammad Saleh Miralam \\ College of Business \\ University of Jeddah, Jeddah, Saudi Arabia \\ Pretty Bhalla \\ Lovely Professional University, Jalandhar, India
}

\section{Key Words}

Organized Retail Sector, Organizational Culture, Autonomy, Trust, Pro-Action, Job Satisfaction

\begin{abstract}
Organizational culture has been characterized as the "glue that holds organizations together". Culture can support linkages between technology adoption and organizational growth; it can be a critical success factor in organization growth strategy and play a crucial role in determining the success or failure of organization. The term 'job satisfaction' is quite frequently used for individual attitudes towards the specific aspects of total work situation. The purpose of the study was to examine the level of Job Satisfaction and Organization Culture in organized retail sector. To examine the relationship between Organizational Culture and Job Satisfaction and to offer suitable suggestions to stake holders for improving the Job Satisfaction and make better Organizational Culture in retail sector. The present study was conducted on 436 employees of organized retail sectors randomly drawn using questionnaire method. The results obtained indicates that the employees were experiencing moderate level of OCTAPACE culture and also moderate level of job satisfaction and dominant culture components includes Openness and Risk taking, Confrontation, Pro-action, Collaboration and Experimentation. It was further explored and found that there is significant positive correlation exists between organizational culture and job satisfaction.
\end{abstract}

Corresponding author: Sayeeduzzafar Qazi

Email address for corresponding author: sayeed@ubt.edu.sa

First submission received: 8th March 2017

Revised submission received: 25th April 2017

Accepted: 21st June 2017

\section{Introduction}

Organizational culture has been characterized as the "glue that holds organizations together". Culture can support linkages between technology adoption and organizational growth; it can be a critical success factor in organization growth strategy and play a crucial role in determining the success or failure of organization. On a more micro level, researchers have found significant relationships between the "fit" of employees and the prevailing organizational culture and a number of important outcomes such as job commitment and turnover. There are many unanswered questions remain regarding the meaning and content of organizational culture, the methods by which it should be measured and, more fundamentally, the feasibility of cultural management and change, especially when attempting to operationalize specific organizational goals. While debates around these issues continue, culture has been accepted as a "fact of organizational life" by managers and has become an integral aspect of many organizational development programs. Culture is a communication process for creating, sending, storing and processing information that is viewed from three perspectives: 
words, material things and behavior (Rothwell et al 1995). The OCTAPACE culture is characterized by the occurrence of openness, confrontation, trust, authenticity, pro-activity, autonomy, collaboration and experimentation, it deals with the extent to which these values are promoted in the organization. (Pareek \& Rao 1988).

Openness \& Risk Taking: Employees feel free to express their ideas and the organization is willing to take risks and to experiment with new ideas and new ways of doing things.

Confrontation: Employees face the problems and work jointly with others concerned to find its solution. They face the issues openly without hiding them or avoiding them for fear of hurting each other.

Trust: The employees department and groups trust each other and can be relied upon to 'do' whatever they say they will do.

Authenticity: Authenticity is the value underlying trust. It is the willingness of a person to acknowledge the feelings he/she has, and to accept him/her as well as others who relate to him/her as persons.

Pro-action: Employees are action - oriented, willing to take initiative and to show a high degree of pro-activity. They anticipate the issues and act or respond to the needs of the future.

Autonomy: Autonomy is the willingness to use power without fear, and helping others to do the same. Employees have some freedom to act independently within the boundaries imposed by their role/job.

Collaboration: Collaboration involves working together and using one another's strength for a common cause. Individuals, instead of solving their problems by themselves, share their concerns with one another and prepare strategies, work out plans of action, and implement them together.

Experimentation: Experimentation as a value emphasizes the importance given to innovation and trying out new ways of dealing with the problems in the organization.

Bullock (2003) described that the job satisfaction as "an attitude which result from balancing and summation of many specific likes and dislikes experienced in connection with the job". Peptone (1999) defined job satisfaction as summation of employees feelings in four important areas namely, job, management, personal adjustment and social relations. Hop Pock (1996) defined employee satisfaction as any combination of psychological, physiological and environmental circumstances that causes the person truthfully to say I am satisfied with my job.

The term 'job satisfaction' is quite frequently used for individual attitudes towards the specific aspects of total work situation. Since the time when the occupation of individuals became a socially significant phenomenon, social scientists focused their attention on the problem of job satisfaction. Inputs affect the outputs via employees' ability and motivation. Job satisfaction is an important aspect for any organizations. Many employers or superiors do not hesitate to know whether or not their employees or subordinates are satisfied with their jobs. Generally, there are four factors that influence the degree of job satisfaction, namely personality, values, work situation and social influence. A research by Karim (2008) reported six variables that significantly correlate with job satisfaction -affective commitment, job autonomy, job performance feedback, role conflict, role clarity and organizational tenure. The research also found that out of these six variables, only two have predictive relationship with job satisfaction: affective commitment and organizational tenure.

\section{Review of literature}

Nazneen et al (2014) conducted a study on 350 employees-218males \& 132 Females drawn randomly from different retail organizations and result shows that the most dominant components of culture in organized retail sector is Confrontation, openness, experimentation and proactively. It is observed from the study that if we create a good culture for the employees, retail would be the best found destination for new graduates and even for the existing employees. 
Saleh (2012) analyzed 62 employees of retail organizations in Malaysia to study level of the job satisfaction, organizational commitment, and turnover intention of employees. The findings suggested that the respondents were moderately satisfied with job satisfaction facets such as promotion, work itself, co-workers, and supervisors but were dissatisfied with salary. They also had moderate commitment level with considerably high intention to leave the organization.

Sabri et al (2011) conducted a research on 347 teachers to determine the effect of organizational culture on job satisfaction level of teachers of public and private sector higher education institutes and universities of Lahore which is second largest city of Pakistan and a hub of higher education. Supportive organizational culture may raise the level of job satisfaction of teachers and satisfied teachers may produce healthy, satisfied and creative minds. Empirical findings show that organizational culture is categorized into two components i.e. organizational culture related to managers and leaders (OCM) and organizational culture related to employees (OCE). In this study effect of both kinds of culture on job satisfaction is positive and significant

Tsai (2011) studied 200 hospital nurses in Taiwan to found out Job satisfaction, organization Culture and leadership behavior among them. He found that there is positive significant relationship between organization culture and job satisfaction. He further found that job satisfaction level among nurses is high and they endorse the culture as positive. Shah (2011) studied 215 faculty members to examine whether organizational culture affects the employee's job satisfaction of university faculty in Public Sector of Pakistan. Result indicated that organizational culture was negatively related to employees' job satisfaction. Thus, the study recommended that the efficiency of the faculty members of public sector universities in Pakistan need to be improved.

Bake and Nalla (2009) studied the relationship between organizational culture and job satisfaction among police officers working in various cities in two Midwestern states in United States. Data for the study was gathered from 669 respondents in five medium and large sized police organizations in two adjacent Midwestern States. More specifically, police officers' (supervisors and non-supervisors) perceptions about organizational factors of job satisfaction was examined and suggested that organizational characteristics are better predictors of job satisfaction than individual factors. Askari (2011) conducted a study to find any relationship between organizational culture and job stress of personnel in government departments at Firozabad city and found that there is a meaningful and negative relationship between organizational culture and job stress and organizational culture is different between men and women.

Nazneen \& Bhalla (2013) conducted a study on 218 male employees and 132 female employees of organized retail sectors and found that the employees of organized retail sectors having moderate level of job satisfaction. They also found that male and female both are showing same level of job satisfaction. They also found negative correlation with the entire dimension of organizational role stress and job satisfaction. Nazneen and Sayeed (2012) conducted a study on 215 faculty members of UP and Punjab and found that faculty members of Punjab are showing low level of job satisfaction than their UP counterparts. Singh \& Dubey (2011) found that job satisfaction was negatively correlated with all the dimensions of organizational role stress among middle level executive. Organizational stress and organizational culture were also found to be negatively correlated among middle level executives and male and female staff of retail. Sector. Askari (2011) conducted a study to find any relationship between organizational culture and job stress of personnel in government departments at Firozabad city and found that there is a meaningful and negative relationship between organizational culture and job satisfaction.

Muzainah et al (2010) found that determining a culture which is appropriate for all organizations is an impossible task because characteristics of organization, its external environment and situational constraints dictate different values, beliefs and behaviors within tax administrations of Malaysia and other developing countries. Pool (1999) studied the organizational role stressors and its impact on job performance in predicting outcome and results indicate that a constructive culture 
will significantly reduce impact of role stress and thereby decreasing job stress, increasing job satisfaction and job commitment.

\subsection{Hypothesis}

We have not formulated any null or alternate hypothesis rather make our research exploratory in nature with following Objectives.....

1.) To examine the level of Job Satisfaction and Organization Culture in organized retail sector.

2.) To examine the relationship between Organizational Culture and Job Satisfaction.

3.) To offer suitable suggestions to stake holders for improving the Job Satisfaction and make better Organizational Culture in retail sector.

\section{Research methodology}

\subsection{Sample}

Employees working in the organized retail sectors with more than two years were taken as Sample and purposive random sampling technique were used to collect the data. Around 500 employees of various retail organizations were contacted in different cities of India and finally 463 employees of various designations, sex, and experience were used as sample.

\subsection{Procedure}

Retail employees from various designation level of different organized retail organizations located in various cities of India like Walmart India, Future Retail, Shoppers Stop, Reliance Retails and Spencer's were selected as a sample keeping in mind the availability of the data, cost and distance for the data collection. Only employees with more than two years of experiences were taken in to consideration. The data were collected using survey method. Each of the respondents was personally contacted in group by the investigator and the data was collected through questionnaire. They were asked to fill the questionnaire after going through carefully the given instructions on each scale separately. They were also assured of confidentiality of their responses.

\subsection{Tools used}

Job Satisfaction Scale: Scale on Job Satisfaction developed by Singh (1989) was used in the study. This questionnaire consists of 20 items that measures the degree of job satisfaction. Each item was rated on five point rating scale ranging from highly satisfied to highly dissatisfied with a weighted score of 5 to 1, the total score of an individual varies from 20-100.

Organizational Culture: Pareek and Rao (1983) developed OCTAPACE profile consisting of 40 items instrument that gives the profile of organizational ethos in 8 values, were used in the study. The total value of an individual will vary between $40-200$.The reliability and validity of all scales are well within acceptable norms.

\section{4 analysis of the data}

The collected data were tabulated as per the research design to meet out the objectives of the study and suitable statistical tools like Mean, Median, S.D., Correlation, ANOVA and Critical ration (t-Value) were calculated using SPSS.

\section{Result and discussion}

Table 1: Showing Mean and SD Values on the Dimensions of Organizational Culture and Job Satisfaction $(\mathrm{N}=463)$.

\begin{tabular}{|l|l|l|}
\hline Components & Mean value & S.D. \\
\hline Openness and Risk Taking & 13.05 & 1.95 \\
\hline Confrontation & 12.97 & 1.89 \\
\hline Trust & 12.27 & 1.90 \\
\hline Authenticity & 12.24 & 2.19 \\
\hline Pro -Action & 12.78 & 2.82 \\
\hline Autonomy & 12.53 & 2.08 \\
\hline Collaboration & 12.99 & 2.34 \\
\hline
\end{tabular}

www.jbrmr.com A Journal of the Academy of Business and Retail Management (ABRM) 


\begin{tabular}{|l|l|l|}
\hline Experimentation & 12.84 & 2.19 \\
\hline Organization Culture & 101.66 & 9.36 \\
\hline Job Satisfaction & 61.08 & 14.15 \\
\hline
\end{tabular}

It can be seen from the Table that OCTAPACE Culture in Organized retail sector of India were found to be at Moderate level and also the employees of organized retail sectors were shown moderate level of Job satisfaction. If we analyze further we can see that on the dimensions of Openness and Risk Taking means employees feels free to express their ideas and the organization is willing to take risks and to experiment new ideas and ways of doing, found to be at moderate level. Collaboration means working together as team and using strength of one another and sharing the problem and concerns with each other and making strategies to resolve those problems and issues together again found at moderate level. Confrontation means employees face the problems and work jointly irrespective of the task and without hurting the feelings and ego of each other and also allowed by the top managers to put their ideas and feelings without any fear also found at moderate level. Experimentation were also found to be at moderate level means there is no much importance given to innovation and trying out new ways in dealing with the problems. Pro-action means the employees are action oriented and willing to take initiatives and anticipate the act or response which may need in future were also found at moderate level.

It was further found that the employees of organized retail sector feels Culture of Trust, Authenticity and Autonomy very poor or at low level. It means the employees, departments and group does not relying and trusting each other while doing any assigned task of the organization and at the same time it was also found that the element of authenticity were also found to be very poor means it is a value underlying trust and it is the willingness of the employees to acknowledge the feelings he or she has and to accept him or her as well as others who relate to him as person in other words we can say that trust whatever we are showing is not authenticated and since there is no elements of Trust operating in this case there is no point of having authenticity culture. The culture of Autonomy were also found to be very low in organized retail sectors here the Autonomy is related with the willingness of the employees to use their power without fear and help others to do the same, in other words employees has given full freedom to their job effectively no boundaries has been imposed on them. This factor is very crucial in retail sector because if employees don't have the freedom or autonomy at work they will not be able to generate and implement new ideas which are needed for the success of retail sectors.

Job satisfaction of the employees of the organized retail sector was found as moderately satisfied and this may be attributed to moderate level of organizational culture.

Table 2: Showing Mean and CR Values of Male and Female Staff on the Dimensions of Organizational Culture and Job Satisfaction

\begin{tabular}{|l|l|l|l|l|l|}
\hline Components & $\begin{array}{l}\text { Mean- Male } \\
(\mathrm{N}-299)\end{array}$ & $\begin{array}{l}\text { SD- Male } \\
(\mathrm{N}-299)\end{array}$ & $\begin{array}{l}\text { Mean- } \\
\text { Male } \\
(\mathrm{N}-164)\end{array}$ & $\begin{array}{l}\text { SD- Male } \\
(\mathrm{N}-164)\end{array}$ & CR Value \\
\hline $\begin{array}{l}\text { Openness and Risk } \\
\text { Taking }\end{array}$ & 13.10 & 1.97 & 12.96 & 1.92 & 0.738 \\
\hline Confrontation & 13.02 & 1.87 & 12.87 & 1.93 & 0.786 \\
\hline Trust & 12.11 & 1.94 & 12.55 & 1.80 & $2.38^{* *}$ \\
\hline Authenticity & 12.22 & 2.16 & 12.27 & 2.26 & 0.267 \\
\hline Pro -Action & 12.91 & 2.81 & 12.52 & 2.82 & 1.422 \\
\hline Autonomy & 12.33 & 2.06 & 12.88 & 2.08 & $2.708^{* *}$ \\
\hline Collaboration & 13.04 & 2.49 & 12.91 & 2.04 & 0.563 \\
\hline Experimentation & 12.84 & 2.13 & 12.85 & 2.31 & 0.067 \\
\hline $\begin{array}{l}\text { Organization } \\
\text { Culture }\end{array}$ & 101.57 & 9.60 & 101.82 & 8.91 & 0.276 \\
\hline Job Satisfaction & 61.08 & 14.15 & 60.68 & 13.87 & 0.298 \\
\cline { 2 - 6 }
\end{tabular}

**: Significant at .05 level of significance

www.jbrmr.com A Journal of the Academy of Business and Retail Management (ABRM) 
It is clear from the Table that Male and Female staff of organized retail sector is experiencing moderate level of Organizational Culture. It is also observed that among Male staff the dominant culture components are Openness and Risk taking, Confrontation, Collaboration and Pro-action while in the case of Female staff the dominant components are Openness and Risk taking, Confrontation, Autonomy and Experimentation. The significant difference of mean were observed on the dimensions of trust and Autonomy between Male and Female staff and it can be seen that in both the cases Female staff are experiencing more Trust and Autonomy in the organization means female staff are trusting and relying each other in individual as well group capacity and willing to do whatever is needed for each other without considering any doubt on the integrity of the co workers. Surprisingly Female staff were shown higher level of Autonomy than Male counter parts and they using they power and authority in more effective way without having any constraint on utilizing those given powers and also not having any constraint in term of utilizing their power and position but the fact is it is only moderate level not at the higher side in both Trust as well as Autonomy components.

No significant difference of means was found on the dimensions of job satisfaction and both male and female employees of organized retail sectors are showing moderate level of job satisfaction.

Table 3: Showing Mean and CR Values of Managerial and Non Managerial Staff on the Dimensions of Organizational Culture and Job Satisfaction

\begin{tabular}{|l|l|l|l|l|l|}
\hline Components & $\begin{array}{l}\text { Mean- } \\
\text { managerial } \\
(\mathrm{n}-160)\end{array}$ & $\begin{array}{l}\text { SD- } \\
\text { managerial } \\
(\mathrm{n}-160)\end{array}$ & $\begin{array}{l}\text { Mean- non } \\
\text { managerial } \\
188)\end{array}$ & $\begin{array}{l}\text { SD- } \\
\text { managerial } \\
(\mathrm{n}-188)\end{array}$ & CR value \\
\hline $\begin{array}{l}\text { Openness and Risk } \\
\text { Taking }\end{array}$ & 12.87 & 1.84 & 13.01 & 1.99 & 0.68 \\
\hline Confrontation & 12.82 & 1.88 & 12.81 & 1.84 & 0.049 \\
\hline Trust & 12.03 & 1.92 & 12.11 & 1.84 & 0.394 \\
\hline Authenticity & 12.29 & 2.29 & 12.22 & 2.17 & 0.291 \\
\hline Pro -Action & 12.32 & 2.89 & 12.74 & 2.70 & 1.392 \\
\hline Autonomy & 12.56 & 2.03 & 12.59 & 2.11 & 0.134 \\
\hline Collaboration & 12.71 & 2.35 & 13.14 & 2.25 & 1.734 \\
\hline Experimentation & 12.54 & 2.06 & 13.03 & 2.31 & $2.091^{* *}$ \\
\hline Organization Culture & 100.14 & 10.25 & 101.64 & 8.13 & 1.633 \\
\hline Job Satisfaction & 56.92 & 13.81 & 61.16 & 13.49 & $2.884^{* *}$ \\
\hline
\end{tabular}

**: Significant at .05 level of significance

As shown in the table that managerial and non managerial employees of the organized retails sectors were experiencing moderate level of organizational culture and no significant differences on organizational culture and their dimensions other than experimentation were found significant. Non managerial employees having greater experimentation than their counterparts mean they were given freedom to innovate new ideas and trying out new methods and techniques in resolving any issues or doing their normal routine work. While on the dimension of job satisfaction it was observed that both managerial and non managerial employees were having moderate level of job satisfaction. And a significant difference of mean was found between managerial and non managerial staff and non managerial employees were shown high level of job satisfaction than their counterparts.

Table 4: Showing Mean and CR Values of High and Low Experience Staff on the Dimensions of Organizational Culture and Job Satisfaction

\begin{tabular}{|l|l|l|l|l|l|}
\hline components & $\begin{array}{l}\text { mean high } \\
\text { expr } \\
(\mathrm{n}-133)\end{array}$ & $\begin{array}{l}\text { SD- high } \\
\text { expr (n-133) }\end{array}$ & $\begin{array}{l}\text { mean- low } \\
\text { expr } \\
(\mathrm{n}-330)\end{array}$ & $\begin{array}{l}\text { SD- low } \\
\text { expr } \\
(\mathrm{n}-330)\end{array}$ & CR- value \\
\hline $\begin{array}{l}\text { Openness and Risk } \\
\text { Taking }\end{array}$ & 13.69 & 1.67 & 12.80 & 2.01 & $4.55^{*}$ \\
\hline Confrontation & 13.53 & 1.76 & 12.74 & 1.90 & $4.11^{*}$ \\
\hline
\end{tabular}

www.jbrmr.com A Journal of the Academy of Business and Retail Management (ABRM) 


\begin{tabular}{|l|l|l|l|l|l|}
\hline Trust & 13.31 & 1.61 & 11.85 & 1.84 & $7.98^{*}$ \\
\hline Authenticity & 12.17 & 2.14 & 12.27 & 2.21 & 0.449 \\
\hline Pro -Action & 14.41 & 2.81 & 12.12 & 2.54 & $8.497^{*}$ \\
\hline Autonomy & 12.35 & 1.64 & 12.60 & 2.22 & 1.190 \\
\hline Collaboration & 13.02 & 2.59 & 12.98 & 2.23 & 0.138 \\
\hline Experimentation & 13.32 & 1.64 & 12.65 & 2.35 & 3.011 \\
\hline Organization Culture & 105.78 & 9.27 & 100.01 & 9.27 & $6.26^{*}$ \\
\hline Job Satisfaction & 61.47 & 17.27 & 60.72 & 12.52 & 0.519 \\
\hline
\end{tabular}

*: Significant at .01 level of significance

It is evident from the above Table that high experienced employees of organized retails sectors were experiencing moderately high level of organizational culture than the low experience employees who feel moderately low level of organizational culture supported the findings of Sayeed and Bhalla (2013). Significant difference of Mean was observed on the dimensions of Openness and Risk Taking, Confrontation, Trust, Pro-Action and total organizational culture. And in all the cases the high experienced employees are experiencing high level of Openness and Risk taking, Confrontation, Trust and Pro-action it means as the time passes in the organization employees feel comfortable and act and perceives the things accordingly. No significance of differences between means were found on the dimension of Authenticity, Autonomy, Collaboration and Experimentation dimension of organizational culture in spite of the fact that there is significant differences of means between high and low experience employees on total organizational culture.

No significant of differences between means were observed on Job satisfaction between high and low experienced employees and the satisfaction level were found to be moderate.

Table 5: Showing Correlation between Organizational Culture and Job Satisfaction among Retail Employees (N 463).

\begin{tabular}{|l|l|l|l|l|l|l|l|l|l|}
\hline OC & O & C & T & A & P & A & C & E & OCT \\
\hline JS & $.323^{*}$ & $.233^{*}$ & $.368^{*}$ & $.248^{*}$ & $.435^{*}$ & $.272^{*}$ & $.420^{*}$ & $.205^{*}$ & $.471^{*}$ \\
\hline
\end{tabular}

*: Significant at .01 level of significance

It is evident from the above Table that all the eight dimension of organizational Culture are significantly (significant at .01 level of significance) and positively correlated with Job satisfaction. It means if we improve the level of perceived organizational culture the job satisfaction level of the employees will also go up and if the perceived organizational culture were found to be low it is expected that job satisfaction level of the employees will also be low. Here in this case both Organizational culture and job satisfaction were perceived as Moderate supporting the study of Bhalla and Nazneen (2014).

Table 5: ANOVA analysis in terms of their designation for the scores on the dimension of Organizational Culture and job satisfaction.

\begin{tabular}{|l|l|l|l|l|l|l|l|l|}
\hline Components & \multicolumn{2}{|l|}{ Senior Level } & \multicolumn{2}{l|}{ Middle Level } & \multicolumn{2}{l|}{ Non Managerial } & & \\
\hline & $\begin{array}{l}\text { MEAN } \\
\text { N-160 }\end{array}$ & SD & $\begin{array}{l}\text { MEAN } \\
\text { N-115 }\end{array}$ & SD & $\begin{array}{l}\text { MEAN } \\
\text { N-188 }\end{array}$ & SD & F - Test & p value \\
\hline Openness & 12.87 & 1.843 & 13.01 & 1.996 & 13.39 & 2.007 & 2.508 & 0.083 \\
\hline Confrontation & 12.83 & 1.879 & 12.81 & 1.843 & 13.42 & 1.942 & $4.423^{*}$ & 0.013 \\
\hline Trust & 12.03 & 1.924 & 12.11 & 1.845 & 12.84 & 1.852 & $7.347^{*}$ & 0.001 \\
\hline Authenticity & 12.29 & 2.286 & 12.22 & 2.172 & 12.20 & 2.112 & 0.066 & 0.937 \\
\hline Pro -action & 12.32 & 2.889 & 12.74 & 2.703 & 13.46 & 2.786 & $5.576^{*}$ & 0.004 \\
\hline Autonomous & 12.56 & 2.033 & 12.59 & 2.111 & 12.37 & 2.105 & 0.421 & 0.657 \\
\hline Collaboration & 12.71 & 2.349 & 13.14 & 2.254 & 13.15 & 2.450 & 1.820 & 0.163 \\
\hline
\end{tabular}

www.jbrmr.com A Journal of the Academy of Business and Retail Management (ABRM) 


\begin{tabular}{|l|l|l|l|l|l|l|l|l|}
\hline Experimentation & 12.54 & 2.065 & 13.03 & 2.309 & 12.97 & 2.138 & 2.435 & 0.089 \\
\hline Organization Culture & 100.14 & 10.24 & 101.64 & 8.130 & 103.81 & 9.596 & $5.227^{*}$ & 0.006 \\
\hline Job satisfaction & 56.92 & 13.81 & 61.16 & 13.494 & 66.17 & 13.543 & $15.491^{*}$ & 0.000 \\
\hline
\end{tabular}

*: Significant at .01 level of significance

ANOVA analysis was conducted for the significant difference between the scores on the dimensions of the organizational culture and job satisfaction among the employees of the retail sector categorized on the basis of their designation.

For the dimension openness, authenticity, autonomous, collaboration and experimentation as $\mathrm{p}$ values obtained were all greater than 0.05 . This signifies that there was no significant difference between the employees categorized on basis of their designation, scores on the all dimension discussed above. For the dimension confrontation as $\mathrm{t}=4.423, \mathrm{p}<0.05$. This signifies that senior and middle level employees score i.e. 12.83 and 12.81 respectively was significantly lower than the scores of the sales representatives i.e. 13.42 .

For the dimension trust as $\mathrm{t}=7.347, \mathrm{p}<0.05$. This signifies that senior and middle level employees score i.e. 12.03 and 12.11 respectively was significantly lower than the scores of the sales representatives i.e. 12.84.The dimension pro-action as $\mathrm{t}=5.576, \mathrm{p}<0.05$. This signifies that senior and middle level employees score i.e. 12.32 and 12.74 respectively was significantly lower than the scores of the sales representatives i.e. 13.46.For the Organization Culture as $t=5.227, p<0.05$. This signifies that senior and middle level employees score i.e. 100.14 and 101.64 respectively was significantly lower than the scores of the sales representatives i.e. 103.81. For the Job Satisfactions $t=15.491$, $\mathrm{p}<$ 0.05. This signifies that senior and middle level employees score i.e. 56.92 and 61.16 respectively was significantly lower than the scores of the sales representatives i.e. 66.17.

\section{Conclusions}

It can be concluded on the basis of above result and discussions that employees of the organized retail sectors are experiencing moderate level of organizational culture and job satisfaction. The dominant OCTAPACE culture dimensions includes Openness and Risk Taking, Confrontation, Pro-action, Collaboration and Experimentation. No significant differences were found between Male and Female employees and both the genders are experiencing moderate level of organizational culture and job satisfaction. The significant difference were observed on the dimensions of job satisfaction between managerial and non managerial employees and non managerial employees are more satisfied than the managerial employees and no difference were found on the dimensions of organizational culture in the same case. It was further found that high experience employees are experiencing high level of organizational culture than low experience employees but no difference were observed on the dimension of job satisfaction level and both the group were having moderate level of job satisfaction. Significant positive correlation were found among the dimensions of OCTAPACE culture components and job satisfaction means if we improve the organizational culture the level of job satisfaction will also go up among the employees of organized retail sector.

\subsection{Suggestions}

To improve the organizational culture it is the responsibility of the Leadership to explore the missing OCTAPACE factors and try to use different OD techniques to improve the organizational culture. Job satisfaction level was also found to be moderate and to increase the level of job satisfaction a more elaborative study should be conducted to know the exact reason beside poor or moderate organizational culture and the intervention should be implemented accordingly as it is very important factor to make an employee efficient and organization effective.

\section{References}

Adcock, P., (1992) A comprehensive study concerning the job satisfaction of Arkansas school superintendents, Unpublished Doctoral Dissertation, East Texas State University, Commerce, Texas 
Ahmad, K. \& Mishra, P.C. (2000): Work motivation, occupational stress and mental health as predictor of organizational commitment. Unpublished Dissertation. Department of Psychology,Lucknow University, Lucknow.

Askari, A.(2011): Any Relationship between organizational culture and job stress among government personnel.(A case study : government department in Firooz Abad city). Journal of basic and Applied Scientific Research. Pg. 1651-1658.

Bake, K.and Nalla,M.K.(2009): Police organizational culture and job satisfaction: A comparison of law enforcement officers perception in two Midwestern states in the U.S, INDD Vol.2 pg 55-73.

Bhalla,P.\&Nazneen,A(2013), "A study of organizational culture in Indian organized retail sectors", International Journal Of Business Management and Research, Issue 4,pp 1-6.

Bhatti, N.Hashmi, M.A., Raza, S.A.Shaikh, F.M. and Shafiq, K.(2011): Empirical analysis of job stress on job satisfaction among university teachers in Pakistan. International business research Vol4, No.3, $\operatorname{Pg} 264-274$.

Bullock LM (2003): 'The Measurement of Organizational Commitment', Journal of Vocational Behaviour: 14: 224-247.

Chandraiah, K., Agarwal,S.C.,Marimuthu, P.,and Manoharan, N.(2003): Occupational stress and job satisfaction among mangers. Indian journal Of Occupational and Environmental medicineVol.7, No.2 .

Hop Pock (1996): Private and Public Sector Managers: An Empirical Investigation to Job Characteristics and Organizational Climate, J. Applied Psychology. 71: 247-259.

Jaafar, M., Ramayah, T., \& Zainal, Z. (2006): Work Satisfaction and Work Performance: How Project Managers in Malaysia Perceived It? Journal of Strategic Management \& Information Technology, Vol. 2, No.1 \&2, Jan.-June.

Karim, N. H. A. (2008): Investigating the Correlates and Predictors of Job Satisfaction Among Malaysian Academics Librarians. Malaysian Journal of Library \& Information Science, 13(2),69-88.

Katzel RA, Barrett RS, Parker TC (1961): Job Satisfaction, Job Performance and Situational Chrematistics, Journal of Applied Psychology 45: 65-72.

Katzel, R.A, Barrett, R.S \& Parker, T.C (1961): Job Satisfaction, Job Performance andSituational Chrematistics, Journal of Applied Psychology 45: 65-72.

Lehal ,R. (2007): A Study of Organizational Role Stress and Job Satisfaction Among Executives in Punjab, IMS JOURNAL 11 .67-80.

Lehal, R. \& Singh, S. (2005): Organizational Role Stress among College Teachers of Patiala District: A Comparative Study of Government and Private Colleges, RIMT, Journal of Strategic Management \& Information Technology, Vol. 2, No.1 \&2, Jan.-June.

Lok,P. and Crawford, J.(2004): Effect of organizational culture and leadership style on job satisfaction and organizational commitment, The Journal of Management development Vol 23no. 4,Pg 321-333.

Muzainah, M. and Mahamad, T.(2010): An empirical examination of organizational culture, job strss and job satisfaction within the Indirect Tax Administration in Malaysia.

Nazneen,A \&Bhalla,P. (2013): "A Study of Organizational Role Stress in Indian Retail Sector", International Journal Of Management Research and Reviews Vol 3/Issue 7.

Nazneen,A\&Bhalla,P. (2014):"A study of ORS and among the Faculty members of Private and Public University", International Journal Of Human Resource Management and Research, vol 3 issue 4 pp-1725

Nirmala (2002): Occupational Stress and Job Performance: A Study in Banking Industry, PlMR, Vol. 6, No. 1-2, April-October.

Pareek, U.(1981): ORS Scale: Measuring Role Stress(mimeo), Indian Institute of Management, Ahmedabad.

Pareek,U (1993) :Making Organizational Role Effective .Tata McGraw Hill Publishing Company Ltd ,New Delhi. 
Pestonjee,D.M (1992) :Role Stress in General Administration: Suggested HRD Intervention',NIRNAYA, vol. 4, No.2, pp. 1-9.

Pool,S.W.(1999): Organizational culture and its relationship between job tension in measuring outcomes among business executives. Journal of Management Development, Vol1 9, No.1, Pg32-49.

Popton RE (1999): 'A Casual Model of Turnover for Nurses, Academy Mgt J. 24: 543-565.

Rothwell, W., Sullivan, R., \& McLean, G. (1995): Practicing Organization Development: A guide for consultants. San Francisco: Jossey-Bass, 432.

Sabri, P.S.U., Ilyas, M., Amjad, Z. (2011) : "Organizational Culture and Its Impact on the Job Satisfaction of the University Teachers of Lahore. International Journal of Business and Social Science",2(24), pp. 121-128.

Saleh R., Nair, M.S., and Harun, H. (2012): "Job Satisfaction, Organizational Commitment, and Turnover Intention: A Case Study on Employees of a Retail Company in Malaysia", World Academy of Science, Engineering and Technology, pp. 316-323.

Sayeed, Sand Ahmad, M. (2002): The Impacts of Employees Job Stress on Organizational commitment. European Journal of Social Sciences - Volume 13, Number 4.

Sayeed, Z. and Bhalla (2013): "A study of organizational role stress in organized retail sectors." International Journal of Management Research and Reviews, Vol-3, Issue VII.

Shah, S.M., Memon, S.M. \&Laghari, M.K. (2011): The impact of organizational culture on employees Satisfaction: A study of faculty members of public sector universities of Pakistan, Interdisciplinary Journal of Contemporary Research in Business. Vol 3, No.8 Pg 847-859.

Sirin, E. F. (2009): Analysis of Relationship between Job Satisfaction and Attitude amongResearch Assistants in Schools of Physical Education and Sports. Journal of Theory and Practice in Education, 5(1), 85 104.

Sullivan, S.M. and Bhagat, R.S. (1992): Organizational Stress, Job Satisfaction and Job Performance: where do we go from here? The Journal of Management Vole 18, No. 2, Pg 353- 374.Vol1, No.1. Pg 82-95.

Tsai, Y. (2011), "Relationship between Organizational Culture, Leadership Behavior and Job Satisfaction", BMC Health Services Research, 11, pp. 98.

P. Vanishree (2014) Impact of Role Ambiguity, Role Conflict and Role Overload on Job Stress in Small and Medium Scale Industries, Research Journal of Management Sciences, ISSN 23191171 Vol. 3(1). 